\title{
Neurobehavioural effects of repeated occupational exposure to toluene and paint solvents
}

\author{
NICOLA CHERRY, HELEN HUTCHINS, T PACE, AND H A WALDRON \\ From the TUC Centenary Institute of Occupational Health, London School of Hygiene and Tropical \\ Medicine, London WC1E 7HT, UK
}

\begin{abstract}
In studies of two workforces 44 men exposed to paint solvents and 52 men working with toluene were compared with age matched comparison groups of non-exposed workers. Scores on a series of performance tests were examined, the solvent exposed in each study functioning less well than their comparison group. The apparent deficit among the paint exposed workers was substantial, but this was reduced after allowance for estimated intellectual capacity. No deficit was apparent on rematching with a second comparison group of more appropriate measured capacity. No evidence was found of impaired nerve conduction in the ulnar or median nerves, and few clinical signs of neurological damage were apparent. Nevertheless, in an associated inquiry of neuropsychological symptoms among 236 painters and 128 non-exposed workers a highly significant excess of symptoms was found among those exposed to paint solvents.
\end{abstract}

Evidence for nervous system effects of long term exposure to organic solvents comes from several sources. Firstly, clinical cases with disabilities attributed to solvent exposure have been intensively studied and a typical clinical pattern of solvent induced changes described. ${ }^{1-6}$ Secondly, there have been several studies of the peripheral nervous system changes associated with exposure to specific solvents or solvent mixtures. ${ }^{7}$ Thirdly, an increased rate of disabling psychiatric illness has been reported in some epidemiological studies carried out in Scandinavia. ${ }^{8-11}$ Finally, several cross sectional studies of signs and symptoms among apparently healthy workers still in employment have been carried out, neurophysiological and behavioural scores among the exposed men being compared with those in an unexposed referent group (see, for example, refs $12-14)$.

The present paper reports two cross sectional studies, using methods previously described..$^{15}$ In study A men were exposed to a mixture of paint solvents in a naval dockyard. In study B exposure was to toluene in the rubber shed of a company manufacturing mineral fibre products.

Received 26 March 1984

Accepted 12 October 1984

\section{Material and methods}

\section{SUBJECTS}

Study $A$ - The men included in study A worked in a large dockyard in the south of England, either as painters or joiners. All had taken part in an earlier questionnaire study in which the painters were found to have raised scores in an English language version of a screening questionnaire ${ }^{16}$ for neuropsychological symptoms developed in Sweden (see appendix). Sixty painters (25\% of the original group) were selected at random and invited to take part in a further study. The selected men, all exposed to paint solvents (see below), were individually matched with a joiner working at the dockyard, those whose tasks exposed them to glues being excluded from the referent group. Matching was on the basis of age ( \pm 3 years), alcohol consumption (regularity of drinking), and, in so far as possible, on the highest levels of examination passed. This procedure resulted in exposed and referent groups, each of 44 men, that were similar in mean age (painters 41.0 years (SD 12.4); joiners 40.8 years (SD 12.1)) and alcohol consumption, but among the painters, a lower proportion had passed public examinations at school or college than had the joiners.

Study $B$ - The men included in study B worked at an asbestos products factory in a process making rubberised asbestos matting that necessitated a high 
exposure to toluene (see below). The aim of the study was to investigate the effects of long term exposure to the solvent, and initially, of the 102 men on the day shift, only the 66 who had worked in the rubber shed for five years or more were invited to take part. Nevertheless, 14 of the 36 men with shorter exposure expressed an interest in undergoing the tests; the relation of such self-selection to the measures used in this study is unknown, but it was thought important that no one should be discouraged, and scores for these 14 volunteers with shorter exposure are included in the analyses reported here.

Among the initial group of 66 with longer exposure, 17 did not wish to take part. This was a higher proportion of non-participants than would normally be accepted, but because of other circumstances in the factory, it was thought inadvisable to press more strongly for participation. It was possible, however, to compare the non-participants and participants on age, duration of exposure, sickness absence, and accident records. The two groups did not differ significantly $(p<0.05)$ on any of these factors.

Each of the 63 subjects finally included (49 long term exposed and 14 volunteers) was individually matched with a man not exposed to solvents and employed elsewhere in the factory. Matching was carried out on age ( \pm 3 years), race (white or Asian) and duration of employment $( \pm 1$ year). Fifty nine well matched pairs were obtained, 52 white and 7 Asian. The mean age of the exposed men was 41.8 years (SD 10.4) and that of the referents, 41.7 years (SD 10.5). Although prior matching on the basis of educational level and alcohol consumption was not possible, examination of questionnaire data showed no difference between the groups on these factors, nor on the taking of medicines or sickness absence.

\section{Exposures}

STUDY A

Table 1 shows the constituents of the most widely used paints in the dockyard. The solvents in the paints included white spirit, trichloroethylene, dichloromethane, methyl n-butyl ketone, and n-butanol. The exact composition of the paints var- $\frac{3}{\infty}$ ied from one manufacturer to another and between $\stackrel{0}{0}$ batches supplied by the same manufacturer. During $\vec{\Rightarrow}$ : the course of his work, a painter might work in the $\stackrel{5}{?}$ open air with relatively low exposure to paint fumes? but also in confined spaces, such as ships' tanks, where exposures would be considerably higher. $A \frac{\bar{s}}{\sigma}$

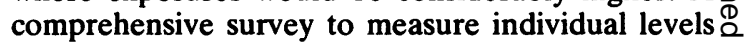
of exposure in the various jobs undertaken by the painters has not been carried out; Kuo, however, $-\vec{O}$ studied eight painters over two days while working in ships accommodation and bilges. ${ }^{17}$ The mean $\vec{\omega}$

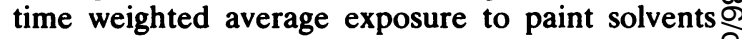
which she found is presented as a guide in table 2 . $\mathbb{\Phi}$ Owing to the varied nature of the painters' work, it 3 was not possible to calculate an index of exposure $\vec{N}$ for each of the men in the study. Nevertheless, the or total years working as a painter at the dockyard is $\tilde{C}_{0}$ used below as a crude index of cumulative exposure; $\vec{\circ}$ the mean duration of exposure was 11.7 years.

\section{STUDY B}

Table 3 shows a summary of measured atmospheric levels of toluene in the rubber shed of the asbestos $\infty$ factory. Before 1976, the levels were at least $300 \mathrm{~N}$ parts per million (ppm) on all the machines in the shed and background levels were between 100 and $200 \mathrm{ppm}$. During the late 1970s, levels fell in all 금 parts of the shed and by December 1981, when the study took place, toluene levels were between $100 \frac{\Omega}{2}$ and $200 \mathrm{ppm}$ on two of the processes, the spike $\underset{\Rightarrow}{\Rightarrow}$ mixers and calenders, and below $100 \mathrm{ppm}$ (the $\frac{0}{3}$ threshold limit value) in other parts of the shed. $\mathrm{An}_{\vec{J}}$ individual index of exposure was computed for each man, each period in years in a given job being weighted by the estimate, shown in table 3 , of $\mathbb{D}$ toluene exposure at that time.

\section{CLINICAL EXAMINATION AND TESTING PROCEDURE}

The same protocol was followed in both studies. Each man was asked to complete a questionnaire at $\mathrm{O}$ home, before the day of his examination, and to give details of job history, symptoms, personal habits

Table 1 Constituents of paints and other materials used at the dockyard

\begin{tabular}{|c|c|c|}
\hline Paint & Solvents & Site of use \\
\hline $\begin{array}{l}\text { White interior } \\
\text { Bitumastic (coal black) } \\
\text { Yellow zinc chromate } \\
\text { Epinamel }\end{array}$ & $\begin{array}{l}\text { White spirit solvent with maximum aromatic content of } 20 \% \\
\text { Methyl n-butyl ketone, n-butanol, xylol, butyl oxitol, solvesso or } \\
\text { cellosolve }\end{array}$ & $\begin{array}{l}\text { Ships' accommodation } \\
\text { Ships' tanks } \\
\text { Primer } \\
\text { Ships' tanks }\end{array}$ \\
\hline $\begin{array}{l}\text { Chlorinated rubber } \\
\text { Epoxy tank coating (Tanclene, } \\
\text { coal tar epoxy) } \\
\text { Paint stripper } \\
\text { French polish }\end{array}$ & $\begin{array}{l}\text { Trimethyl benzene, xylol, shellsol, or naptha } \\
\text { Xylol, trimethyl benzene, white spirit, cellosolve, n-butanol diacetone } \\
\text { alcohol } \\
\text { Trichloroethylene or dichloromethane } \\
\text { White spirit }\end{array}$ & $\begin{array}{l}\text { Machinery spaces } \\
\text { Ships' tanks } \\
\text { Paint removal } \\
\text { Varnished surfaces }\end{array}$ \\
\hline
\end{tabular}


Table 2 Mean levels of exposure to organic solvents for eight painters on two working days in September 1980 (after $\mathrm{KuO}^{17}$ )

\begin{tabular}{|c|c|c|c|c|}
\hline Paint & Principal solvent & $\begin{array}{l}\text { Mean time weighted } \\
\text { average }\left(\mathrm{mg}^{\prime} \mathrm{m}^{3}\right)\end{array}$ & $T L V\left(m g / m^{3}\right)$ & No of painters \\
\hline $\begin{array}{l}\text { White interior } \\
\text { Paint stripper } \\
\text { Chlorinated rubber }\end{array}$ & $\begin{array}{l}\text { White spirit } \\
\text { Dichloromethane } \\
\text { White spirit }\end{array}$ & $\begin{array}{l}577 \cdot 4 \\
214 \cdot 7 \\
124 \cdot 6\end{array}$ & $\begin{array}{l}525 \cdot 0 \\
700 \cdot 0 \\
525 \cdot 0\end{array}$ & $\begin{array}{l}4 \\
1 \\
3\end{array}$ \\
\hline
\end{tabular}

Table 3 Sampled levels of toluene by job and by year in the rubber shed

\begin{tabular}{|c|c|c|c|c|c|c|c|c|c|c|c|c|}
\hline \multirow[t]{2}{*}{$J o b$} & \multicolumn{12}{|l|}{ Pre- } \\
\hline & 1970 & 1971 & 1972 & 1973 & 1974 & 1975 & 1976 & 1977 & 1978 & 1979 & 1980 & 1981 \\
\hline $\begin{array}{l}\text { Spike mixer } \\
\text { Other mixer } \\
\text { Surface weigher } \\
\text { Body weigher } \\
\text { Calendar operator } \\
\text { General background }\end{array}$ & $\begin{array}{l}\frac{6}{6} \\
6 \\
4 \\
2\end{array}$ & $\begin{array}{l}6 \\
6 \\
6 \\
4 \\
2\end{array}$ & $\begin{array}{l}6 \\
6 \\
4 \\
4 \\
2\end{array}$ & $\begin{array}{l}6 \\
6 \\
4 \\
4 \\
2\end{array}$ & $\begin{array}{l}6 \\
4 \\
6 \\
4 \\
4 \\
2\end{array}$ & $\begin{array}{l}6 \\
4 \\
6 \\
4 \\
4 \\
2\end{array}$ & $\begin{array}{l}3 \\
2 \\
6 \\
3 \\
4 \\
2\end{array}$ & $\begin{array}{l}3 \\
2 \\
6 \\
2 \\
3 \\
2\end{array}$ & $\begin{array}{l}3 \\
2 \\
2 \\
2 \\
3 \\
1\end{array}$ & $\begin{array}{l}3 \\
2 \\
2 \\
2 \\
3 \\
1\end{array}$ & $\begin{array}{l}2 \\
2 \\
2 \\
2 \\
2 \\
1\end{array}$ & $\begin{array}{l}2 \\
1 \\
1 \\
1 \\
2 \\
1\end{array}$ \\
\hline
\end{tabular}

$1=0-100 \mathrm{ppm} ; 2=100-200 \mathrm{ppm} ; 3=200-300 \mathrm{ppm} ; 4=300-400 \mathrm{ppm} ; 5=400-500 \mathrm{ppm} ; 6=>500 \mathrm{ppm}$.

(smoking, drinking), and examinations passed. When he reported to the medical centre at his place of work on the day of testing he was clinically examined, with particular attention being given to the nervous system. The physician responsible for the examination then checked the medical and exposure history with the worker, the rest of the research team, who were to conduct the further tests, not being informed of the exposure status ("exposed" or "comparison").

The behavioural testing procedure outlined below was carried out immediately after the clinical examination. Each man was tested alone in a quiet room away from the normal work of the medical centre. The procedure lasted from 30 to 50 minutes, depending on the capacities of the worker. The final stage of the assessment was the measurement of nerve conduction velocities in the ulnar and median nerves of the right arm using a Medelec MS7. Motor and sensory components of the nerves were measured (the method is described more fully elsewhere $\left.{ }^{18}\right)$.

\section{BEHAVIOURAL TESTS}

The series of behavioural tests was identical in the two studies. The tests are described briefly below; they have been described in more detail elsewhere together with the details of the scoring procedure. ${ }^{19}$ The tests used have been shown to be sensitive in differentiating patients with minor brain damage from other groups of neurological patients at a rehabilitation centre..$^{20}$

Dotting tests-The test session started with a simple pencil and paper dotting test, in which the man was asked to place dots, as rapidly as possible, on either side of two parallel lines $10.5 \mathrm{~cm}$ apart during the space of 10 seconds. The total number of dots was recorded. The man then repeated the test, for a further period of 10 seconds, the task at this stage being to make dots inside two circles of $1 \mathrm{~cm}$ radius, the centres of the circles being $10.5 \mathrm{~cm}$ apart. The total number of dots within the circles was counted.

Trail making tests - The test ${ }^{21}$ required the subject to join $\mathbf{2 5}$ circles with a pencil mark. In the first part of the test the circles contained the numbers from 1 to 25 and the subject was required to join the circles in the correct numerical order. In the second part of the test 13 numbers (1-13) and 12 letters $(A-L)$ were shown in the circles and the subject was required to join alternate numbers and letters (1A-2-B. . .). The time taken to complete each series was recorded.

Visual search test-In this test (adapted from Goldstein et $^{a^{22}}$ ) the subject was presented with a series of checkerboard grids consisting of 81 black and white squares. Each white square was divided into 25 smaller squares, two of which were filled in black. The configuration and arrangement of the large white squares was constant with the exception of the centre square which varied from grid to grid. The subject's task was to search for the white square in the grid which was identical with the centre square. Twelve timed trials were given and the mean time calculated.

Digit symbol test ${ }^{23}$ - The subject was required to substitute symbols for the numbers $1-9$, making as many substitutes as possible in $\mathbf{9 0}$ seconds. The total number of correct substitutions was recorded.

Block design test ${ }^{23}$ - The subject was presented with nine blocks having two red sides, two white sides, and two sides diagonally divided into red and white halves. The blocks were used to construct a 
series of ten designs that were presented on cards in order of increasing difficulty. The test was scored according to the highest ranking design successfully completed and the time taken to complete each trial.

Grooved pegboard test-For this test, apparatus supplied by Lafayette Instrument Company was used. The subject placed 25 key shaped pegs into holes that had the flange of the key arranged in random order. The time to complete the task was measured with the subject using first his preferred and then his non-preferred hand.

Simple unprepared reaction time ${ }^{24}$-The test measured the subject's mean speed of response to some 80 signals presented at random intervals of 1-10 seconds for a period of ten minutes; the test used here was modified to mask feedback and so eliminate any differential motivational effect this might have provided for the exposed and nonexposed groups.

Memory test ${ }^{25}$ - The subject was presented with a list of 20 animal names which he was asked to recall. $\mathrm{He}$ was reminded of those that he had forgotten and this procedure was carried out for five trials. From the results it was possible to calculate the number of items recalled on each of the five trials, the total over the five trials, the number of long term store after four trials and the number of intrusions - that is, animal names - that were not on the original list.

Reading test-The final test to be administered was the National Adult Reading Test, ${ }^{26}$ originally designed to assess the level of intellectual attainment before the onset of damage to the central nervous system. The subject was asked to read a list of 50 words with irregular pronunciation that were presented in order of increasing difficulty, and he was scored according to the number that he pronounced correctly. The fifty words in the test were selected in such a way that they cannot be pronounced by applying the normal graphemephoneme and stress rules of the English language and may be read correctly only if previously known to the reader. This test is resistant to the effects of recent central nervous system damage.

\section{Results}

\section{CLINICAL EXAMINATION}

In nine of the painters and five of the joiners some loss of vibration was noted in the arms or legs. This difference was entirely accounted for by differences in the use of vibrating tools. In study B vibration loss in the legs was noted in 11 of the exposed and five of the non-exposed men. This result is suggestive of some effect of the solvent but was not statistically significant.
NEUROPHYSIOLOGICAL MEASURES

Using a matched pair $t$ test, none of the neurophysiological measures, motor conduction $\vec{\Rightarrow}$ velocity, sensory conduction velocity, amplitude, $\stackrel{\rho}{\rightarrow}$ and distal latency in the ulnar and median nerves differed significantly between either group of solvent workers and their controls. The largest difference between the groups was for sensory conduction velocity in the ulnar nerves of the workers exposed के to toluene and their controls; however, this difference was only $1.5 \mathrm{~m} / \mathrm{sec}$ and was not significant at the $5 \%$ level.

\section{BEHAVIOURAL TESTS}

Matched pair $t$ tests were carried out to compare the performance of the exposed men with their comparison group.

Study $A$-Table 4 shows the results for this comparison of the scores of men exposed to paint solvents and their non-exposed referent group. The $\frac{\circ}{5}$ painters had a lower mean score on the reading test; this is discussed in more detail below. They also performed less well on the alternating part of the trail making test, with a longer mean correct response time on the visual search and a lower mean score on of the block design test. They were also slower on the grooved pegboard test with each hand, and their overall mean reaction time was slower than the joiners. In the memory test, the painters recalled fewer items than the joiners over five trials, they had fewer items in long term store on the fourth trial, and made more intrusions during the test. All these differences were statistically significant $(p<0.05)$.

Study $B$-The referent group once again had a higher score on the reading test than the exposed group (see table 5), this difference being unlikely to have arisen by chance $(p<0 \cdot 01)$. Differences between groups on the other tests did not reach statistical significance, but scores on four tests, the trail making test (alternating series), the visual search, the pegboard test (with either hand), and the number of intrusions on the memory test (instrusions) sug- 을 gested, using a one tailed approach that may be $D$ more appropriate given the hypothesis under test, that the exposed group performed less well. It may $N$ be noted that scores on all tests, except for the reaction time, were somewhat worse for the exposed than for the non-exposed workers.

\section{CUMULATIVE EXPOSURE AND PERFORMANCE}

In a working population age and exposure measures $\overparen{\Phi}$ based on duration of employment will be positively $\stackrel{\oplus}{+}$ correlated. In a study of behavioural effects in which 70 test scores decline with age assessment of the effects of cumulative exposure may be interpreted only after full allowance for the effects of aging, prefer- $\mathbb{D}$ 
Table 4 Mean performance of painters and their controls

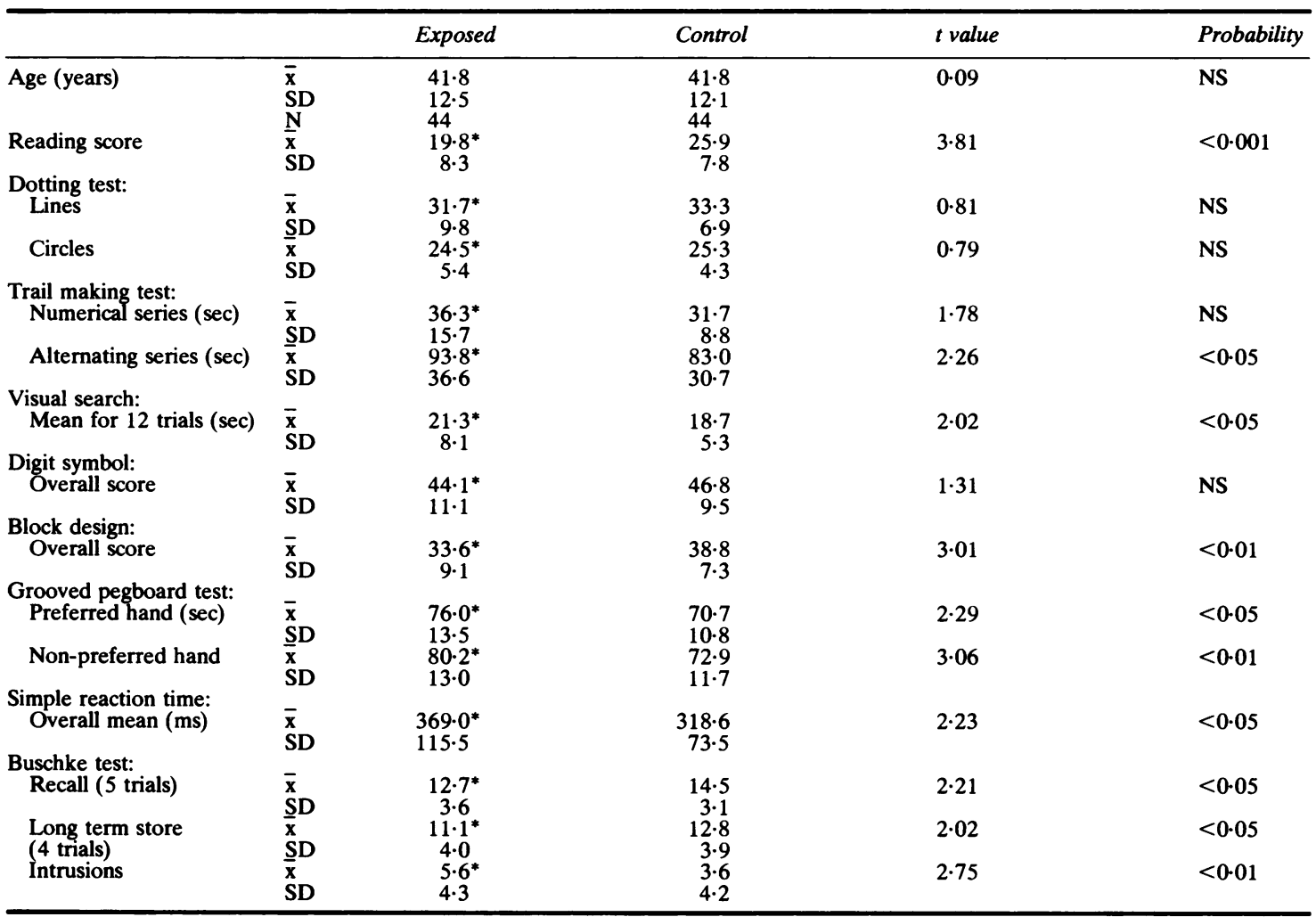

${ }^{*}$ Group with worse performance.

ably estimated in the non-exposed population. In the present study the years of total exposure, or, for toluene, the index of cumulative exposure, were related to performance on the behavioural tests. These analyses, which were restricted to men with occupational exposure, evaluated the contribution of exposure after allowance for age.

Study $A-$ Having allowed for age, years of exposure appeared to have a greater effect on the grooved pegboard test (with the non-preferred hand) than on any of the other measures; painters with long exposures took longer to complete this task than men of the same age with shorter exposures. The level of statistical significance, however, was not high (5\%), and with 13 tests being carried out one such result might reasonably be expected to have arisen by chance.

Study $B$-After allowance for age, the weighted cumulative index described above was not related to any of the behavioural test scores among the men exposed to toluene.

\section{ADJUSTMENT FOR READING SCORE}

In both study $A$ and study $B$ the exposed men obtained lower scores than their comparison group on the reading test. This test had been designed to assess level of verbal attainment (and hence, indirectly, intellectual capacity) before the onset of any damage to the central nervous system that might have resulted from exposure to solvents. The results on this test suggested that the comparison groups were of higher ability than the exposed men with whom they had been matched. Because of the correlation between the reading test scores and the performance tests found even in the non-exposed men it was necessary to allow for these differences in verbal attainment in assessing the effects of exposure on performance. Two approaches were adopted.

\section{Statistical adjustment for reading scores}

Study $\boldsymbol{A}-\mathbf{A}$ multiple regression analysis was carried out in which the effects of job (exposed to paint solvents or not) were assessed after allowance for 
Table 5 Mean performance of toluene workers and their controls, Asian workers omitted

\begin{tabular}{|c|c|c|c|c|c|}
\hline & & Exposed & Control & $t$ value & Probability \\
\hline Age (years) & $\begin{array}{l}\overline{\mathbf{x}} \\
\mathbf{S D} \\
\mathbf{N}\end{array}$ & $\begin{array}{l}42 \cdot 0 \\
10 \cdot 5 \\
52\end{array}$ & $\begin{array}{l}41 \cdot 9 \\
10 \cdot 7 \\
52\end{array}$ & 0.59 & NS \\
\hline Reading score & $\begin{array}{l}\mathrm{x} \\
\mathrm{SD}\end{array}$ & $\begin{array}{c}17 \cdot 6^{*} \\
9 \cdot 5\end{array}$ & $\begin{array}{r}21 \cdot 7 \\
8 \cdot 6\end{array}$ & 2.79 & $<0.01$ \\
\hline $\begin{array}{l}\text { Dotting test: } \\
\text { Lines }\end{array}$ & $\overline{\mathbf{x}}$ & $\begin{array}{r}35 \cdot 0 \\
8.0\end{array}$ & $\begin{array}{c}34.4^{*} \\
7.8\end{array}$ & 0.37 & NS \\
\hline Circles & SD & $\begin{array}{r}25.7 \\
4 \cdot 8\end{array}$ & $\begin{array}{c}24 \cdot 9^{*} \\
4 \cdot 5\end{array}$ & 0.91 & NS \\
\hline $\begin{array}{l}\text { Trail making test: } \\
\text { Numerical series }(\mathrm{sec})\end{array}$ & $\begin{array}{l}\overline{\mathbf{x}} \\
\mathbf{S D}\end{array}$ & $35 \cdot 2^{*}$ & $32 \cdot 7$ & $0 \cdot 85$ & NS \\
\hline Alternạting series (sec) & $\begin{array}{l}\frac{3}{x} \\
\text { SD }\end{array}$ & $\begin{array}{l}96 \cdot 0^{*} \\
49 \cdot 0\end{array}$ & $\begin{array}{l}10.0 \\
79.5 \\
25.9\end{array}$ & 1.93 & NS \\
\hline $\begin{array}{l}\text { Visual search: } \\
\text { Mean for } 12 \text { trials }(\mathrm{sec})\end{array}$ & $\begin{array}{l}\bar{x} \\
\text { SD }\end{array}$ & $\begin{array}{c}22 \cdot 8^{*} \\
7 \cdot 1\end{array}$ & $\begin{array}{r}20 \cdot 5 \\
5 \cdot 1\end{array}$ & 1.97 & NS \\
\hline $\begin{array}{l}\text { Digit symbol: } \\
\text { Overall score }\end{array}$ & $\begin{array}{l}\overline{\mathbf{x}} \\
\text { SD }\end{array}$ & $\begin{array}{l}42 \cdot 1^{*} \\
12 \cdot 8\end{array}$ & $\begin{array}{r}45 \cdot 7 \\
9 \cdot 1\end{array}$ & $1 \cdot 52$ & NS \\
\hline $\begin{array}{l}\text { Block design: } \\
\text { Overall score }\end{array}$ & $\begin{array}{l}\bar{x} \\
\text { SD }\end{array}$ & $\begin{array}{c}31.2^{*} \\
9.2\end{array}$ & $\begin{array}{r}34.0 \\
7.8\end{array}$ & 1.63 & NS \\
\hline $\begin{array}{l}\text { Grooved pegboard test: } \\
\text { Preferred hand }(\mathrm{sec})\end{array}$ & $\begin{array}{l}\bar{x} \\
S D\end{array}$ & $\begin{array}{l}80.4^{*} \\
19.4^{2}\end{array}$ & $\begin{array}{l}75 \cdot 2 \\
10 \cdot 9\end{array}$ & 1.74 & NS \\
\hline Non-preferred hand & $\begin{array}{l}\text { SND } \\
\text { SD }\end{array}$ & $\begin{array}{l}85 \cdot 5^{*} \\
19 \cdot 0\end{array}$ & $\begin{array}{l}79 \cdot 5 \\
12 \cdot 0\end{array}$ & 1.94 & NS \\
\hline $\begin{array}{l}\text { Simple reaction time: } \\
\text { Overall mean (ms) }\end{array}$ & $\begin{array}{l}\overline{\mathbf{x}} \\
\mathrm{SD}\end{array}$ & $\begin{array}{r}321 \cdot 1 \\
68 \cdot 6\end{array}$ & $\begin{array}{c}328 \cdot 6^{*} \\
68 \cdot 6\end{array}$ & 0.56 & NS \\
\hline $\begin{array}{l}\text { Buschke test: } \\
\text { Recall ( } 5 \text { trials) }\end{array}$ & $\begin{array}{l}\overline{\mathbf{x}} \\
\mathrm{SD}\end{array}$ & $\begin{array}{c}12.7^{*} \\
3.0\end{array}$ & $\begin{array}{r}13 \cdot 5 \\
3.2\end{array}$ & $1 \cdot 50$ & NS \\
\hline $\begin{array}{l}\text { Long term store } \\
\text { ( } 4 \text { trials) } \\
\text { Intrusions }\end{array}$ & 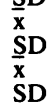 & $\begin{array}{c}10 \cdot 7^{*} \\
3 \cdot 1 \\
5 \cdot 9^{*} \\
4 \cdot 5\end{array}$ & $\begin{array}{r}11.7 \\
3.5 \\
4 \cdot 1 \\
4.6\end{array}$ & $1 \cdot 46$ & NS \\
\hline
\end{tabular}

*Group with worse performance.

ability, as measured by the reading test. Scores on four of the performance tests were found to relate $(p<0.05)$ to the type of job (exposed or not) even after this statistical adjustment. These were block design (total score), pegboard test (with nonpreferred hand), reaction time (mean), and memory test (number of intrusions).

Study B-A similar analysis was carried out on the scores of the men exposed to toluene and their comparison group. As before, no significant relation was found between exposure group and test score. The mathematical model used in this adjustment does not allow for measurement error associated with the reading test. Such error may result in biased adjustment when the population means of the two samples differ, ${ }^{27}$ inclusion of the test score adjusting inadequately for the "true" underlying effect of intellectual capacity. This bias does not arise if the samples are drawn from populations with similarly distributed values of the covariate. An opportunity to investigate the effects of paint solvents without this source of bias arises here from the similarity of the reading test scores in the comparison group in study $B$ and the exposed group in study $A$. The mean and standard deviations on age and reading score for the men recruited from these populations are shown in table 6; no difference in reading score is apparent. It was decided to reanalyse the data using the unexposed group from study B as a comparison group for study A. It seemed that this approach would avoid the possible statistical bias associated with measurement error in the reading test; however, other biases resulting from differences in the testing environment and study populations may have been introduced in using this comparison group.

Table 6 Mean age and reading score of 48 painters and 57 non-exposed white workers at the rubber factory

\begin{tabular}{|c|c|c|c|c|c|}
\hline & & Painters & Non-exposed & $t$ value & Probability \\
\hline $\begin{array}{l}\text { Age } \\
\text { (years) }\end{array}$ & $\begin{array}{l}\bar{x} \\
\text { SD }\end{array}$ & $\begin{array}{l}41 \cdot 7 \\
12 \cdot 0\end{array}$ & $\begin{array}{l}39.9 \\
14.0\end{array}$ & 0.97 & NS \\
\hline $\begin{array}{l}\text { Reading } \\
\text { score }\end{array}$ & $\begin{array}{l}\bar{x} \\
\text { SD }\end{array}$ & $\begin{array}{r}19.9 \\
8.1\end{array}$ & $\begin{array}{l}20 \cdot 5 \\
10 \cdot 0\end{array}$ & 0.46 & NS. \\
\hline
\end{tabular}


Redefinition of the comparison group for study $A$ The painters in study $A$ were individually rematched on age ( \pm 3 years) and reading score ( \pm 3 points) with non-exposed white workers from study $B$. Thirty four well matched pairs were obtained. A comparison of test scores for these pairs is shown in table 7. On only one test, reaction time, is the difference between groups sufficiently large to suggest a systematic effect.

\section{Discussion}

The studies reported here have shown few effects that may be attributed to solvent exposure. A slight excess of minor peripheral nervous system deficits was noted in the clinical examination in both exposed groups but cannot with certainty be attributed to solvent exposure. No difference of importance was found on the limited range of neurophysiological measures of peripheral nervous system function.

On the performance tests, men in exposed jobs, particularly the dockyard workers exposed to paint solvents, appeared to do appreciably less well than their comparison group; however, having carried out the best available matching for reading ability (as an estimate of intellectual capacity), only the reaction time test suggested any deficit in performance among the painters. The workers exposed to toluene seemed to perform somewhat less well than their comparison group, but the statistical uncertainty associated with these results was such as to prevent any firm conclusion of damage. The relation of cumulative exposure to performance is also unremarkable, no relation being found for the toluene workers and only one, possibly chance, effect being related to duration of exposure among the men working with paint solvents. These results do not suggest any widespread subclinical change resulting from occupational exposure to either toluene or to the mixtures of paint solvents used in the dockyard chosen for the investigation.

The negative findings in the clinical and neurophysiological examinations do not require lengthy discussion; although in at least one study ${ }^{13}$ paint solvents have been reported as affecting nerve

Table 7 Mean performance of painters and toluene factory controls

\begin{tabular}{|c|c|c|c|c|c|}
\hline & & Exposed & Control & $t$ value & Probability \\
\hline Age (years) & $\begin{array}{l}\bar{x} \\
\text { SD } \\
\underline{N}\end{array}$ & $\begin{array}{l}42 \cdot 7 \\
11 \cdot 8 \\
34\end{array}$ & $\begin{array}{l}42 \cdot 4 \\
10 \cdot 5 \\
34\end{array}$ & 0.82 & NS \\
\hline Reading score & $\begin{array}{l}\mathrm{x} \\
\mathrm{SD}\end{array}$ & $\begin{array}{c}20.4^{*} \\
7.6\end{array}$ & $\begin{array}{r}20 \cdot 6 \\
8 \cdot 4\end{array}$ & 0.47 & NS \\
\hline $\begin{array}{l}\text { Dotting test: } \\
\text { Lines }\end{array}$ & $\begin{array}{l}\bar{x} \\
s\end{array}$ & $\begin{array}{c}31 \cdot 8^{*} \\
9 \cdot 8\end{array}$ & $\begin{array}{r}34 \cdot 7 \\
8 \cdot 2\end{array}$ & $1 \cdot 32$ & NS \\
\hline Circles & $\begin{array}{l}\mathrm{x} \\
\mathrm{SD}\end{array}$ & $\begin{array}{r}25 \cdot 1 \\
5 \cdot 7\end{array}$ & $\begin{array}{c}24 \cdot 7^{*} \\
4 \cdot 6\end{array}$ & 0.32 & NS \\
\hline $\begin{array}{l}\text { Trail making test: } \\
\text { Numerical series (sec) }\end{array}$ & $\begin{array}{l}\bar{x} \\
\text { SD }\end{array}$ & $\begin{array}{l}35 \cdot 8^{*} \\
15 \cdot 2\end{array}$ & $\begin{array}{l}33 \cdot 4 \\
10 \cdot 8\end{array}$ & $0 \cdot 80$ & NS \\
\hline Alternating series $(\mathrm{sec})$ & $\begin{array}{l}\mathrm{x} \\
\mathrm{SD}\end{array}$ & $\begin{array}{l}93 \cdot 3^{*} \\
36 \cdot 5\end{array}$ & $\begin{array}{l}80 \cdot 2 \\
25 \cdot 9\end{array}$ & 1.47 & NS \\
\hline $\begin{array}{l}\text { Visual search: } \\
\text { Mean for } 12 \text { trials (sec) }\end{array}$ & $\begin{array}{l}\bar{x} \\
S D\end{array}$ & $\begin{array}{r}20 \cdot 6 \\
8 \cdot 3\end{array}$ & $\begin{array}{c}20 \cdot 8^{*} \\
4 \cdot 7\end{array}$ & $0 \cdot 10$ & NS \\
\hline $\begin{array}{l}\text { Digit symbol: } \\
\text { Overall score }\end{array}$ & $\begin{array}{l}\bar{x} \\
\text { SD }\end{array}$ & $\begin{array}{l}45 \cdot 0 \\
10 \cdot 7\end{array}$ & $\begin{array}{r}45 \cdot 0 \\
9 \cdot 5\end{array}$ & $0 \cdot 01$ & NS \\
\hline $\begin{array}{l}\text { Block design: } \\
\text { Overall score }\end{array}$ & $\begin{array}{l}\bar{x} \\
S D\end{array}$ & $\begin{array}{r}34 \cdot 7 \\
8 \cdot 6\end{array}$ & $\begin{array}{l}33 \cdot 2^{*} \\
8 \cdot 0\end{array}$ & $0 \cdot 88$ & NS \\
\hline $\begin{array}{l}\text { Grooved pegboard test: } \\
\text { Preferred hand (sec) }\end{array}$ & $\begin{array}{l}\bar{x} \\
S D\end{array}$ & $\begin{array}{l}75 \cdot 8 \\
12 \cdot 6\end{array}$ & $\begin{array}{l}76 \cdot 3^{*} \\
12 \cdot 2\end{array}$ & $0 \cdot 18$ & NS \\
\hline Non-preferred hand & $\begin{array}{l}\mathrm{x} \\
\mathrm{SD}\end{array}$ & $\begin{array}{l}80 \cdot 0^{*} \\
11 \cdot 9\end{array}$ & $\begin{array}{l}79.7 \\
13.2\end{array}$ & $0 \cdot 11$ & NS \\
\hline $\begin{array}{l}\text { Simple reaction time: } \\
\text { Overall mean (ms) }\end{array}$ & $\begin{array}{l}\bar{x} \\
\text { SD }\end{array}$ & $\begin{array}{l}380 \cdot 2^{*} \\
125 \cdot 5\end{array}$ & $\begin{array}{r}331 \cdot 3 \\
74 \cdot 5\end{array}$ & $1 \cdot 97$ & NS \\
\hline $\begin{array}{l}\text { Buschke test: } \\
\text { Recall ( } 5 \text { trials) }\end{array}$ & $\begin{array}{l}\bar{x} \\
\text { SD }\end{array}$ & $\begin{array}{r}12.9 \\
3.6\end{array}$ & $\begin{array}{r}12 \cdot 9 \\
3 \cdot 4\end{array}$ & $0 \cdot 00$ & NS \\
\hline $\begin{array}{l}\text { Long term store } \\
\text { ( } 4 \text { trials) } \\
\text { Intrusions }\end{array}$ & $\begin{array}{l}\frac{N}{x} \\
\text { SDD } \\
x \\
\text { SD }\end{array}$ & $\begin{array}{c}11 \cdot 1^{*} \\
4 \cdot 0 \\
5 \cdot 7^{*} \\
3 \cdot 9\end{array}$ & $\begin{array}{r}11.3 \\
3.5 \\
4.5 \\
5 \cdot 2\end{array}$ & $\begin{array}{l}0 \cdot 20 \\
1.07\end{array}$ & $\begin{array}{l}\text { NS } \\
\text { NS }\end{array}$ \\
\hline
\end{tabular}

*Group with worse performance. 
conduction, the findings for toluene are inconclusive (see for example, Cavanagh ${ }^{28}$ ). More sensitive methods of investigation, however, might have been able to detect minimal changes in function in the peripheral nervous system that were not apparent with those adopted here. The failure to find a relation between duration of exposure and performance deficit is consistent with earlier studies; it is to be noted, however, that a repeated failure to demonstrate this relation must throw some doubt on the hypothesis that cumulative long term damage results as exposure is extended. Of greater interest, however, is the absence of subclinical deficits in performance tests. This finding is at odds with many of the published studies of workers exposed to the groups of solvents investigated here.

The studies reporting such deficits were carefully carried out and fully reported. For example, Arlien-Soborg et al and Hane and her colleagues reported that painters were significantly impaired on tests of memory, reaction time, psychomotor coordination, and concept formation. ${ }^{12}$ In two other Scandinavian studies of car painters exposed to toluene Elofsson $e t$ al found that the exposed men were significantly worse on tests of memory, perceptual speed, reaction time, and manual dexterity by comparison with a non-exposed referent group ${ }^{13}$ whereas Hänninen found exposed men to be impaired on measures of memory, psychomotor co-ordination and non-verbal skills. ${ }^{14}$ Such differences in findings between these studies and those reported here do not seem reasonably attributable either to absolute levels of exposure (the workers investigated by Hänninen, for example, being exposed to a mean concentration of only $31 \mathrm{ppm}$ of toluene) or, in our view, to synergistic effects that may be hypothesised to result from solvent mixtures. While perhaps the inclusion of volunteers in study B and the somewhat low rate of participation in both studies may have reduced the power of the investigation, it is nevertheless unexpected in the light of the results of other studies, that no substantial effect of solvents is apparent.

In interpreting the lack of consistency between the final results (table 7) of the present study and published accounts of others of similar design, it may be appropriate to consider the conclusions that might have been drawn (from table 5) if there had not, by chance, been the possibility of carrying out an alternative adjustment for pre-exposure intellectual capacity. Without this, the poorer performance of the solvent workers might have been more readily attributed to solvent exposure. The methodology adopted in this and in previously published cross sectional studies is subject to the distorting effects of confounding factors and may be of little use in inves- tigating causal relation unless it can be shown that $\frac{3}{\infty}$ plausible alternative explanation may be rejected. In $?$ the present study effects apparently attributable to solvent exposure disappear with rematching; this finding puts in doubt the causality of the previously shown relation between exposure to paints and performance, and permits no firm conclusion as to the existence of solvent induced deficit in the populations investigated in the two studies reported here.

\section{Appendix}

PRELIMINARY QUESTIONNAIRE STUDY OF NEUROPSYCHOLOGICAL SYMPTOMS AMONG DOCKYARD PAINTERS

In June and July 1980 an English language version of the screening questionnaire for solvent workers devised by Hogstedt et $\mathbf{l l}^{\mathbf{2 9}}$ was administered to 236 painters and 128 joiners working in a naval dockyard. All men shown as employed as a painter or joiner on the payroll on 2 May 1980 were approached to take part in the study but co- operation was voluntary. The sample completing the $ळ$ questionnaire represented $84 \%$ of painters and $73 \%$. of joiners. To investigate the representativeness of $\square$ the participants a comparison was made of age and sickness absence records for the participants and non-participants. No significant difference was found on age, spells of absence, or total days of $\mathbb{Q}$ certified or uncertified sickness. Among those who $\vec{\Rightarrow}$ took part in the study, no difference was found between painters and joiners on age (painters mean $\vec{\partial}$ age 40.9 years, joiners 42.7 years), marital status, cigarette smoking, medication, or reported alcohol intake. The joiners, however, had passed significantly more examinations at school or college than had the painters.

The questionnaire used was slightly modified from the English version published by Hogstedt and his colleagues, the wording of questions being adapted to more common English usage. The form of the questionnaire was, however, the same, 15 questions $\frac{7}{0}$ on solvent related symptoms and one question acting as a detector item for over reporting. In this o questionnaire the subject is required to report whether recently (over the past few weeks) he has $N$ experienced each symptom.

The questionnaire was administered to the painters and joiners by one of the authors (TP) or by a member of the nursing staff at the dockyard. Groups $\mathbb{\Phi}$ of between six and 22 men completed the question-? naire at any one time in a room set aside for the survey. The administrators completed the questionnaire on behalf of 17 men who were unable to do so themselves. The questionnaire responses of the 
seven men who omitted answers to two or more questions were excluded from the analysis.

The responses of the painters and joiners were compared for both individual questions and for the total of positive replies. The mean number of positive responses was significantly higher $(p<0.01)$ for the painters (mean $3 \cdot 7$, SD $3 \cdot 5$ ) than for the joiners (mean $2 \cdot 6$, SD $3 \cdot 2$ ), the painters being more likely to report each symptom. The four individual questions with a significantly higher response by the painters are shown in table 8 . Using the threshold scores suggested by Hogstedt et al to identify cases for referral to a physician (four or more symptoms for workers aged 27 or under and six or more for older workers), the number of "cases" among the painters and joiners was computed. Sixty of the painters were identified as "cases" compared with 15 of the joiners, a highly significant difference (table 9).

Table 8 Numbers of painters and joiners responding positively to four items on the solvent questionnaire

\begin{tabular}{|c|c|c|c|c|}
\hline & Painters & Joiners & $x^{2}$ & $p$ \\
\hline $\begin{array}{l}\text { Do you often have } \\
\text { painful tingling in } \\
\text { your hands or feet? }\end{array}$ & $\begin{array}{l}60 \\
(25 \cdot 9 \%)\end{array}$ & $\begin{array}{l}13 \\
(10 \cdot 3 \%)\end{array}$ & $11 \cdot 22$ & $<0.001$ \\
\hline $\begin{array}{l}\text { Do you often feel } \\
\text { irritated for no } \\
\text { particular reason? }\end{array}$ & $\begin{array}{l}79 \\
(34 \cdot 1 \%)\end{array}$ & $\begin{array}{l}29 \\
(23 \cdot 0 \%)\end{array}$ & $4 \cdot 21$ & $<0.05$ \\
\hline $\begin{array}{l}\text { Do you often feel } \\
\text { depressed for no } \\
\text { particular reason? }\end{array}$ & $\begin{array}{l}68 \\
(29 \cdot 3 \%)\end{array}$ & $\begin{array}{l}24 \\
(19 \cdot 0 \%)\end{array}$ & 3.98 & $<0.05$ \\
\hline $\begin{array}{l}\text { Do you often have } \\
\text { difficulty } \\
\text { concentrating? }\end{array}$ & $\begin{array}{l}62 \\
(26 \cdot 8 \%)\end{array}$ & $\begin{array}{l}20 \\
(16.0 \%)\end{array}$ & $4 \cdot 78$ & $<0.05$ \\
\hline
\end{tabular}

Table 9 Number of cases defined by the solvent questionnaire

\begin{tabular}{llc}
\hline & Painters & Joiners \\
\hline Non-case & 170 & 112 \\
Case & $(73.9 \%)$ & $(88.2 \%)$ \\
& 60 & 15 \\
& $(26.1 \%)$ & $(11.8 \%)$ \\
\hline
\end{tabular}

No consistent relation was found between educational level and symptom reporting, and the difference between groups shown in table 2 could not be attributed to the reported difference on this factor. The men taking part in the study could not be effectively blinded, however, as the hypothesis under test and the possibility of reporting bias could not be ruled out. In order to investigate more fully the possibility of solvent effects among the painters, the follow up study reported above was devised.

These studies were supported by a grant from the Colt Foundation. We would like to express our appreciation of this funding and also the cooperation and help provided by the workers and medical services concerned. Parts of the work reported here have been presented in theses for higher degrees of the University of London.

\section{References}

' Arlien-Soborg P, Bruhn P, Gyldensted C, Melgaard B. Chronic painters' syndrome: chronic toxic encephalopathy in house painters. Acta Neurol Scand 1979;60:149-56.

${ }^{2}$ Bruhn P, Arlien-Soborg P, Gyldensted C, Christensen EL. Prognosis in chronic toxic encephalopathy. Acta Neurol Scand 1981;64:259-72.

${ }^{3}$ Hernberg S. Does solvent poisoning exist? In: Cherry N, Waldron HA, eds. The neuropsychological effects of solvent exposure. Havant: Colt Foundation, 1983:63-74.

${ }_{4}^{4}$ Juntenen J, Hernberg S, Eistola P, Hupli V. Exposure to industrial solvents and brain atrophy. A retrospective study of pneumoencephalographic findings among 37 patients with exposure to industrial solvents. Eur Neurol 1980;19:366-75.

5 Juntenen J, Hupli V, Hernberg S, Luisto M. Neurological picture of organic solvent poisoning in industry. A restrospective study of 37 patients. Int Arch Occup Environ Health 1980;46:219 31.

- Antti-Poika M. Prognosis of symptoms in patients with diagnosed chronic organic solvent intoxication. Int Arch Occup Environ Health 1982;51:81-9.

7 Venables H. Solvent-induced peripheral neuropathy in man. In: Cherry N, Waldron HA, eds. The neuropsychological effects of solvent exposure. Havant: Colt Foundation, 1983:23-7.

${ }^{8}$ Axelson $\mathrm{O}$, Hane M, Hogstedt C. A case-referent study on neuropsychiatric disorders among workers exposed to solvents. Scand J Work Environ Health 1976;2:14-20.

Axelson O. Epidemiology of solvent-related neuropsychiatric disorders. In: Cherry N, Waldron HA, eds. The neuropsychological effects of solvent exposure. Havant: Colt Foundation, 1983:85-99.

${ }^{10}$ Mikkelson S. A cohort study of disability pension and death among painters with special regard to disabling presenile dementia as an occupational disease. Scand J Soc Med (suppl) 1980;16:34-43.

" Olsen J, Sabroe S. A case-reference study of neuropsychiatric disorders among workers exposed to solvents in the Danish wood and furniture industry. Scand $J$ Soc Med (suppl) 1980;16:44-9.

${ }^{12}$ Hane M, Axelson O, Blume J, Hogstedt C, Sundell L; Ydreborg B. Psychological function changes among house painters. Scand J Work Environ Health 1977;3:91-9.

${ }^{13}$ Elofsson SA, Gamberale F, Hindmarsh T, et al. Exposure to organic solvents: a cross-sectional epidemiologic investigation on occupationally exposed car and industrial spray painters with special reference to the nervous system. Scand J Work Environ Health 1980;6:239-73.

${ }^{14}$ Hänninen $H$, Eskelinen $L$, Husman $K$, Nurminen $M$. Behavioural effects of long-term exposure to a mixture of organic solvents. Scand J Work Environ Health 1976;2:24055.

${ }^{15}$ Cherry N, Venables H, Waldron HA, Wells GG. Some observations on workers exposed to methylene chloride. Br J Ind Med 1981;38:351-5.

${ }^{16}$ Hogstedt C, Hane M, Axelson O. Diagnosis and health care aspects of workers exposed to solvents. In: Zenz C, ed. Developments in occupational medicine. Chicago: Year Book Medical Publishers, 1980:249-58.

17 Kuo YL. The effects of exposure to organic solvents on human behaviour. London: University of London, 1980. (MSc dissertation.) 
${ }^{18}$ Venables H, Waldron HA. Normal values for use in neurophysiological studies of male manual workers. In: Cherry $\mathbf{N}$, Waldron HA, eds. The neuropsychological effects of solvent exposure. Havant: Colt Foundation, 1983:30-2.

${ }^{19}$ Cherry N, Venables H, Waldron HA. A test battery to measure the behavioural effects of neurotoxic substances. London: TUC Centenary Institute of Occupational Health, London School of Hygiene \& Tropical Medicine, 1982.

${ }^{20}$ Venables H. An investigation of the neuropsychological effects of long term occupational exposure to organic solvents. London: University of London, 1983. (PhD thesis.)

${ }^{21}$ Reitan RM. Trail making test. Manual for administration, scoring and interpretation. Tucson, Arizona: Neuropsychological Laboratory, 1338 Edison St. (Undated mimeograph.)

${ }^{22}$ Goldstein G, Welch RB, Rennick PM, Shelley CH. The validity of a visual searching task as an indicator of brain damage. $J$ Consult Clin Psychol 1973;41:434-7.

${ }^{23}$ Saville P. A British supplement to the manual of the Wechsler adult intelligence scale. Windsor: NFER Publishing Company,
1971.

24 Wilkinson RT, Houghton D. Field test of arousal: a portable reaction timer with data storage. Human Factors 1982;24:487-93.

${ }^{25}$ Buschke $H$. Selective reminding for analysis of memory and learning. Journal of Verbal Learning and Verbal Behaviour $1973 ; 12: 543-50$.

${ }^{26}$ Nelson HE. The Nelson adult reading test (NART) manual. London: National Hospital for Nervous Diseases, 1977.

${ }^{27}$ Cochran WG. Errors of measurement in statistics. Technometrics 1968; 10:637-66.

${ }^{28}$ Cavanagh J. Some clinical and neuropathological correlations in four solvent intoxications. In: Cherry $\mathrm{N}$, Waldron HA, eds. The neuropsychological effects of solvent exposure. Havant: Colt Foundation, 1983:7-19.

${ }^{29}$ Hogstedt $\mathrm{C}$, Hane M, Axelson $\mathrm{O}$. Diagnosis and health care aspects of workers exposed to solvent. In: Zenc C, ed. Developments in occupational medicine. Chigaco: Year Book Medical Publishers, 1980:249-58. 